\title{
Current status of fish-borne zoonotic trematode infections in Gia Vien district, Ninh Binh province, Vietnam
}

Nguyen Manh Hung ${ }^{1 *}$, Do Trung Dung ${ }^{2}$, Nguyen Thi Lan Anh ${ }^{3}$, Phan Thi Van ${ }^{4}$, Bui Ngoc Thanh ${ }^{4}$, Nguyen Van Ha ${ }^{1}$, Hoang Van Hien ${ }^{1}$ and Le Xuan Canh ${ }^{1}$

\begin{abstract}
Background: Ninh Binh province is known as an endemic area of fish-borne zoonotic trematode (FZT) transmission in Vietnam. A cross-sectional study was conducted in Gia Minh and Gia Thinh communes of Gia Vien district, Ninh Binh province to investigate the infections with different stages of FZT in various host species.

Methods: Faecal samples from 1,857 humans were examined for trematode eggs using the Kato-Katz method, while faecal samples from 104 dogs, 100 cats, and 100 pigs were examined using the Formalin-ethyl acetate concentration technique (FECT). A total of 483 specimens of freshwater fish, representing 9 species, were examined for metacercariae using the artificial digestion method. Three methods of cercarial detection (shedding, crushing and cutting) were applied for examination of 3,972 specimens of freshwater snails, representing 7 species. All relevant data e.g. location, sex, age group, animal species, and habitat were recorded for statistical analyses.

Results: Helminth eggs were found in $65.5 \%$ of the human faecal samples, including $20.5 \%$ of faecal samples containing small trematode eggs. Infection with small trematodes differed among communes, age groups and sexes. Eggs of small trematodes were found in 32.7\% of faecal samples from dogs, $49.0 \%$ from cats and $13.0 \%$ from pigs. The difference in prevalences and intensities were significant among species of animals but did not differ between the two communes. All fish species were infected with FZT, with an average prevalence of $56.1 \%$ and a mean intensity of 33.245 metacercariae per gram. Prevalence and intensity in fish differed significantly among cummunes and fish groups. Six species of zoonotic trematodes were identified. Metacercariae of the small liver fluke, Clonorchis sinensis, was only found in Hemiculter leucisculus. A total of 9 specimens from two snail species, Melanoides tuberculata and Bithynia fuchsiana, were infected with trematodes and four cercarial types were detected in the study sites.
\end{abstract}

Conclusions: We conclude that Gia Minh and Gia Thinh communes are continuing to be hot-spot endemic areas of FZT and other helminths infections where the habit of eating raw fish by the local people is still present.

Keywords: Small trematode eggs, Clonorchis sinensis, Intestinal trematodes, Intermediate host, Aquaculture

\footnotetext{
* Correspondence: hung_iebr@yahoo.com

${ }^{1}$ Institute of Ecology and Biological Resources (IEBR), Vietnam Academy of Science and Technology, 18 Hoang Quoc Viet St., Cau Giay district, Hanoi, Vietnam

Full list of author information is available at the end of the article
} 


\section{Background}

Fish-borne zoonotic trematodes (FZT) are transmitted by fish and fish products, and pose a major public health problem [1-3]. People become infected with FZT after ingesting raw or undercooked freshwater fish containing infective metacercariae [3-5]. Recently, a total of 59 FZT species, which are known to parasitize humans, are listed [6]. All species can be divided into two groups, the first being the small liver flukes (Opisthorchiidae: 12 species), and the second the minute intestinal flukes (Heterophyidae: 36 species, Echinostomatidae: 10 species and Nanophyetidae: 1 species) [6]. Adults of the small liver flukes parasitize the liver (bile ducts and gall bladder) of their definitive host, where they can cause serious diseases in humans. Cholangitis, choledocholithiasis, pancreatitis, and cholangiocarcinoma are the major clinical problems associated with chronic infections $[7,8]$. Individuals with light infections usually show no symptoms. Intestinal flukes are generally not of considerable clinical importance compared to the liver flukes, but several species may cause significant pathology sometimes fatal; in the heart, brain, and spinal cord of humans [9-13]. Eggs of intestinal flukes are difficult to differentiate from those of liver flukes, often causing misdiagnosis and inaccurate estimates of the prevalence of both trematode groups $[14,15]$.

The worldwide number of people currently infected with small liver flukes only exceeds 45 million [4]. Among them, 35 million people are infected with Clonorchis sinensis, including 15 million Chinese [16,17], 10 million people are infected with Opisthorchis viverrini [4] and 1.6 million people are infected with O. felineus [18] including 1.5 million people in the former Union of Soviet Socialist Republics [19]. The estimates of at-risk populations for clonorchiasis and opisthorchiasis are 601 million and 80 million, respectively [4]. In cases of small intestinal flukes, an estimated 40 to 50 million people are infected with one or several species $[4,20]$, with more than half a billion at risk of infection [21,22]. In Vietnam, 12 FZT species have been found in humans and mammals, including 3 small liver fluke species and 9 minute intestinal fluke species [6]. Seven FZT species have only been detected in humans: Clonorchis sinensis, Opisthorchis viverrini (Opisthorchiidae), Centrocestus formosanus, Haplorchis pumilio, $H$. taichui, $H$. yokogawai, Stellantchasmus falcatus (Heterophyidae). Estimates of people infected with small liver flukes were 2 million [4], with unknown millions infected with intestinal flukes. The number of infected people with intestinal flukes is believed to be higher than the number of people infected with small liver flukes [23].

We conducted a study in Gia Vien district, Ninh Binh province from August 2011 to February 2012. This area has a proverb "Nắng gỏi, mưa cày" meaning the local people delight in eating raw fish during the dry season and dog meat in the rainy season. The habit of eating raw fish by people here is the only reason to explain the high prevalence of small liver fluke infections, according to previous surveys [24-26]. Our survey aimed to clarify the parasitological status of FZT infections in different hosts, including first intermediate hosts (snails), second intermediate hosts (fishes), and the definitive hosts (humans and mammals).

\section{Methods}

\section{Study site}

Two communes, Gia Minh and Gia Thinh in Gia Vien district, Ninh Binh province, were selected for crosssectional surveys. These communes are known as heavily clonorchiasis-endemic areas in Northern Vietnam. The population in Gia Thinh commune was 7,615, including 1,228 families, while in Gia Minh commune the population was 2,791 with 512 families. Because of flooding in the rainy season caused by Hoang Long River, farmers in both communes do not have fish ponds integrated into their farming systems, (e.g. pig farming, vegetable garden) as other rural areas. Most of the residents are living on rice agriculture; however, some farmers rely on fish cage cultures in the rivers, dams, and lakes.

\section{Examination of human and domestic animal fecal samples}

Households in these two communes were randomly selected from a list provided by community authorities. In each selected household, all members of the family, age 2 years or older, were chosen for the study. The trained personnel gave labeled plastic bags to the selected persons older or equal to 9 years of age and instructed them on how to collect and store their fecal sample until it was returned the next day. For instances where participants were under the age of 9 , the proxy helped in the collection of the fecal sample. The leader of the household also collected fecal sample from domestic animals (dogs, cats and pigs) and returned them together with the human fecal samples. Human fecal samples were labeled with the participant's name, age, address, and date of stool collection. Animal fecal samples were labeled with the name of the householder, the animal species, ordinal number if the household had more than one individual of a species, address, and date of stool collection. Human and animal fecal samples were examined by the National Institute of Malariology, Parasitology and Entomology (NIMPE) and National Institute of Veterinary Research (NIVR), separately. Fecal samples were kept at $4^{\circ} \mathrm{C}$ in the laboratory. A total of 1,857 people, $104 \mathrm{dog}, 100$ cats and 100 pigs were examined in both communes.

Kato-Katz thick smear method was applied to examine human fecal samples. Each fecal sample was prepared for one Kato-Katz smear and analyzed using a standard kit 
provided to NIMPE by the World Health Organization and originally obtained from Vestegaard Frandsen Pvt. Ltd. (New Delhi, India). Fecal slides were examined by light microscopy $(\times 400)$ to identify helminth eggs. Identification of helminthic eggs based on morphological features detailed by WHO [27]. Fecal samples of animals were examined using a Formalin-ethyl acetate concentration technique (FECT) [28] for finding only trematode eggs. All trematode eggs which had a size smaller than $50 \mu \mathrm{m}$ were designated "small trematode eggs" [23,29,30]. The infection intensity of trematode eggs was calculated for each sample.

\section{Fish sampling and examinations}

Fish samples were collected from different water bodies, e.g. rivers, lakes, dams, and small canals, and were divided into two groups. The first group represented cultured fishes and the second wild-caught fishes. The term "wild-caught fish" refers to fish collected outside the aquaculture systems [31]. The culture fishes were collected from cage cultures, at the study sites, at one site in the Gia Thinh commune and 5 sites in the Gia Minh commune. The wild-caught fishes were collected from 15 different locations in each commune. Fishes in cages, dams and lakes were collected using a cast net, used in each of the four corners of each water body [31]. All fish caught from the four throws were used for examination. For fish living in rivers and canals, dip-nets were used for collections. In each location, the dip-net was used 5 times. The period of rest between dip-net use was $30 \mathrm{mi}-$ nutes. A total of 483 fish, belonging to 9 species, were collected and examined, including 172 culture fish specimens. After collecting, fish samples were preserved on ice and transported, same day, to the Center for Environment and Disease Monitoring in Aquaculture (CEDMA), RIA1. In the laboratory, fish were maintained at $4^{\circ} \mathrm{C}$ for a maximum of 5 days until processed. Each fish was examined using an artificial digestion method, described by WHO [32] and modified by Tran et al. [33]. Small fishes (less than $200 \mathrm{~g}$ in weight) were ground and digested whole, while only $50 \mathrm{~g}$ sub-sample from larger fishes (more than $200 \mathrm{~g}$ ) were ground, mixed, and digested for recovery of metacercariae. Metacercariae of each type were counted and recorded.

Metacercariae were identified according to morphological features detailed by Pearson \& Ow-Yang [34], Scholtz et al. [35] and Kaewkes [36]. Infection intensities of metacercariae were calculated for each sample.

\section{Snail sampling and examination}

Thirty locations, representing all available habitats in each commune, were selected for snail collecting. Drainage canals nearby households were intensely sampled, with 15 sites, due to the heavy risk factor for food-borne zoonotic trematode infections associated with them [37]. Other habitats included rivers (2 sites), lakes (2 sites), dams (2 sites) and rice fields (9 sites). Rice fields were selected as far away as possible from one another to insure that all hamlets were represented at least once.

Snails were collected during the morning hours for 20 minutes per site by scooping $[37,38]$ and/or handpicking, transferred to plastic containers and transported alive to the laboratory where they were identified according to keys by Brandt [39] and Dang [40].

All snails, depending on their size, were examined for trematode infection using one or more of the following methods: shedding, crushing, and/or cutting. For the shedding method smaller snails were placed individually in small plastic containers with $5 \mathrm{ml}$ of water each and left for 24 hours to shed cercariae. Snails were checked for shedding in the late afternoon and again the following morning. This procedure can be used for larger snails except they should be kept in larger containers with more water. The advantage of this method is the ability to obtain clean cercariae. The crushing method involves crushing whole snails between two glass plates while the cutting method (only done on large snails with rigid shells) involved cutting open the shell and transferring tissue parts and hemolymph to a glass slide. When checked under a stereomicroscope, several stages of trematode larvae (cercaria (old and young), sporocysts, and rediae) could be observed. Cercarial groups were identified to major types according to the keys of Ghihencinskaja [41], Shell [42] and other available references; more specific identification was not made.

\section{Statistical analysis}

Data were entered into an Excel database (Microsoft Corporation, Redmond, WA, USA) and analyzed using statistical analysis software (STATA 12; StataCorp LP, College Station, TX, USA).

Trematode egg count data from human samples were transformed to binomial data. Cases with infection of any FZT species were coded to "1" and uninfected cases were coded to " 0 ". Occurrence (present/absence) of FZT in humans was analyzed using logistic regression, with commune, sex, and age group as predictors after adjusting for possible clustering within families and hamlet [43]. The age of participants was divided into three categories: under working-age group $(<19)$, working-age group (19-59), and over working-age group (>59). Similarly, infections in domestic animals and fish were analyzed using logistic regression, with species or fish group and commune as predictors, while infections in snails used snail species, habitat, and commune as predictors.

Intensity of FZT infections in humans, domestic animals, and fish was analyzed in a similar fashion, using negative binomial regression and reported as count ratios, 
Table 1 Helminth infections in humans living in Gia Minh and Gia Thinh communes

\begin{tabular}{llll}
\hline Helminths & $\begin{array}{l}\text { Gia Minh (no. exam: 895) } \\
\text { No. positive (prevalence in \%) }\end{array}$ & $\begin{array}{l}\text { Gia Thinh (no. exam: 962) } \\
\text { No. positive (prevalence in \%) }\end{array}$ & $\begin{array}{l}\text { Total examination: 1,857 } \\
\text { No. positive (prevalence in \%) }\end{array}$ \\
\hline Small trematodes & $84(9.4)$ & $297(30.9)$ & $381(20.5)$ \\
Ascaris lumbricoides & $410(45.8)$ & $132(13.7)$ & $542(29.2)$ \\
Trichuris trichuira & $547(61.1)$ & $389(40.4)$ & $836(45.0)$ \\
Hookworm & $25(2.8)$ & $7(0.7)$ & $32(1.7)$ \\
Other & $5(0.6)$ & $12(1.2)$ & $17(0.9)$ \\
Total infection & $685(76.5)$ & $532(55.3)$ & $1,217(65.5)$ \\
\hline
\end{tabular}

i.e. in generalized linear model with log-link function [44]. The ancillary parameter was estimated using full maximum likelihood estimation.

Differences with p-values below 0.05 were considered significant.

\section{Ethical aspects}

The human study was approved by NIMPE, while NIVR approved the study of domestic animals. Before the start of the study, all selected households had been given information about the study and volunteered to participate in the study. All infected cases (both human and animal) were treated with anthelmintic free of charge at the conclusion of the study.

\section{Results}

\section{Helminth infection in humans}

Results for helminth and small trematode infections in humans using fecal egg examinations are summarized in Table 1 and Table 2. A total of 1,217 persons were infected with helminths (65.5\%). Eggs of small trematodes were found in $20.5 \%$ of fecal samples. Nematode eggs of whipworm (Trichuris trichiura), roundworm (Ascaris lumbricoides), hookworm and other parasites were detected in $45 \%, 29.2 \%, 1.7 \%$ and $0.9 \%$ of fecal samples, respectively. Multiparasitism was common in the study sites, with $36.1 \%$ of participants having eggs of more than one species or type of eggs.
The prevalence and intensity of small trematodes in Gia Thinh commune were 4.62 times $(\mathrm{p}<0.001)$ and 1.2 times $(p=0.009)$ higher than those in Gia Minh commune, respectively. Infection with small trematodes also differed between age groups and sex. The rate of infection and intensity in men were 2.99 and 1.82 times greater than in women $(\mathrm{p}<0.001)$. The working-age group and over working-age group had prevalences 6.79 and 6.81 times higher than in the under working-age group ( $\mathrm{p}<0.001)$. Similarly, the intensity of small trematode infections in the working-age group and over working-age group were 1.8 and 2 times higher than in the under working-age group $(\mathrm{p}<0.001)$. There was no significant difference in small trematode infections between working-age group and over working-age group.

Infections with hookworms did not differ significantly by sex, age group, or commune ( $p>0.05)$. The prevalence and intensity of Trichuris trichiura in Gia Minh commune were 2.5 and 9.4 times higher than those in Gia Thinh commune $(p<0.001)$, however, there were no significant differences among age groups and sexes. In cases of Ascaris lumbricoides, infections differed significantly among commune, sex, and age group. Prevalence and intensity of round worm infections in Gia Minh commune were 3.8 and 11.2 times higher than those in Gia Thinh commune $(\mathrm{p}<0.001)$. The under working age group had infection prevalences 1.7 and 1.9 times higher than in the workingage and over working-age groups $(\mathrm{p}<0.001)$, however there were no significant differences between the working-

Table 2 Prevalence of small trematode infections in relation to age group and sexes

\begin{tabular}{|c|c|c|c|c|c|c|c|c|c|}
\hline \multirow[t]{2}{*}{ Commune } & \multirow{2}{*}{$\begin{array}{l}\text { Age } \\
\text { group }\end{array}$} & \multicolumn{4}{|l|}{ Male } & \multicolumn{4}{|l|}{ Female } \\
\hline & & No. examined & No. positive & $\begin{array}{l}\text { Prevalence } \\
(\%)\end{array}$ & $\begin{array}{l}\text { Mean intensity } \\
\text { (range) }\end{array}$ & No. examined & No. positive & $\begin{array}{l}\text { Prevalence } \\
(\%)\end{array}$ & $\begin{array}{l}\text { Mean intensity } \\
\text { (range) }\end{array}$ \\
\hline \multirow[t]{3}{*}{ Gia Minh } & $<19$ & 142 & 2 & 1.4 & $48(48-48)$ & 163 & 6 & 3.7 & $204(24-696)$ \\
\hline & $19-59$ & 162 & 37 & 22.8 & $245.8(24-2,760)$ & 271 & 20 & 7.4 & $328.8(24-1,920)$ \\
\hline & $>59$ & 61 & 15 & 24.6 & $297.6(24-1,560)$ & 96 & 4 & 4.2 & $156(24-480)$ \\
\hline \multirow[t]{3}{*}{ Gia Thinh } & $<19$ & 82 & 11 & 13.4 & $24.3(1-252)$ & 68 & 7 & 10.3 & $5.9(1-30)$ \\
\hline & $19-59$ & 275 & 148 & 53.8 & $33.5(1-810)$ & 391 & 75 & 19.2 & $31.3(1-1,200)$ \\
\hline & $>59$ & 54 & 28 & 51.9 & $55.7(1-470)$ & 92 & 28 & 30.4 & $107.1(1-1,520)$ \\
\hline Total & & 776 & 241 & 31.1 & & 1081 & 140 & 13.0 & \\
\hline
\end{tabular}


Table 3 Prevalence and intensity of FZT infections in domestic animals in Gia Minh and Gia Thinh communes

\begin{tabular}{|c|c|c|c|c|c|c|c|c|c|c|c|c|}
\hline \multirow[t]{2}{*}{ Commune } & \multicolumn{4}{|l|}{ Dogs } & \multicolumn{4}{|l|}{ Cats } & \multicolumn{4}{|l|}{ Pigs } \\
\hline & $\begin{array}{l}\text { No. of } \\
\text { samples }\end{array}$ & $\begin{array}{l}\text { No. of positive } \\
\text { samples }\end{array}$ & $\begin{array}{l}\text { Prevalence } \\
\text { (\%) }\end{array}$ & $\begin{array}{l}\text { Mean intensity } \\
\text { (range) }\end{array}$ & $\begin{array}{l}\text { No. of } \\
\text { samples }\end{array}$ & $\begin{array}{l}\text { No. of positive } \\
\text { samples }\end{array}$ & $\begin{array}{l}\text { Prevalence } \\
\text { (\%) }\end{array}$ & $\begin{array}{l}\text { Mean intensity } \\
\text { (range) }\end{array}$ & $\begin{array}{l}\text { No. of } \\
\text { samples }\end{array}$ & $\begin{array}{l}\text { No. of positive } \\
\text { samples }\end{array}$ & $\begin{array}{l}\text { Prevalence } \\
\text { (\%) }\end{array}$ & $\begin{array}{l}\text { Mean intensity } \\
\text { (range) }\end{array}$ \\
\hline Gia Minh & 51 & 18 & 35.3 & $258.8(51-628)$ & 40 & 23 & 57.5 & $125.4(58-487)$ & 57 & 4 & 7.0 & $16.3(8-25)$ \\
\hline Gia Thinh & 53 & 16 & 30.2 & $229.6(84-592)$ & 60 & 26 & 43.3 & $132.2(73-520)$ & 43 & 2 & 4.7 & $13.5(10-17)$ \\
\hline Total & 104 & 34 & 32.7 & & 100 & 49 & 49.0 & & 100 & 6 & 6.0 & \\
\hline
\end{tabular}


age and over working-age groups. Similarly, the intensity of round worm infections in the under working-age group was higher than in the working-age and over working-age groups $(\mathrm{p}<0.001)$. The odds ratios were 2.9 and 3.0 , respectively. Women had prevalence and intensity of round worm infection $1.6(\mathrm{p}=0.001)$ and 1.4 $(\mathrm{p}=0.004)$ times higher than men.

\section{Prevalence and intensity of small flukes in animals}

Results of examination of animal samples for small trematodes are summarized in Table 3. Prevalence of small fluke infections was $32.7 \%$ in dogs, $49.0 \%$ in cats, and $13.0 \%$ in pigs. The difference in prevalence and intensity between dogs, cats and pigs was significant $(\mathrm{p}<0.05)$. Prevalence of infection was highest in cats and lowest in pigs, while the intensity was highest in dogs and lowest in pigs. There were no significant differences in prevalence and intensity of small trematode infections between the two communes for dogs, cats, or pigs ( $p>0.05)$.

\section{Infection status of FZT in fish}

A total of 483 fish, representing nine species, were examined for FZT. Among them, the Crucian carp, tilapia, and common carp were the dominant species, comprising $68.9 \%$ of the total number of examined fishes (Table 4). All fish species were infected by FZT at different prevalences. The average prevalence was $56.1 \%$ with a mean intensity of 33.245 metacercariae per gram (Table 5). Several fish species showed high prevalence of infections, i.e. Anabas testudineus (96.8\%), Channa striata (85.7\%) and Carassius auratus (79.6\%). The lowest prevalence was found in Labeo rohita (11.4\%).

The prevalence and intensity of FZT in fish from Gia Thinh commune were 2.5 and 1.5 times higher than in fish from Gia Minh commune $(\mathrm{p}<0.005)$, respectively. The wild-caught fish group had prevalence of FZT 5.1 times higher than in the culture fish group $(\mathrm{p}<0.001)$. Similarly, the intensity of FZT metacercariae in the wildcaught fish group was 1.8 times greater than in the culture fish group.

A total of six species of zoonotic trematodes was identified, including Haplorchis pumilio, H. taichui, H. yokogawai, Centrocestus formosanus, Procerovum varium (Heterophyidae), and Clonorchis sinensis (Opisthorchiidae) (Table 6). Numerous metacercariae could not be identified to genus or species because they died or were too young; therefore, they were listed as unidentified. Metacercariae of the liver fluke, C. sinensis, was only found in the sharpbelly, with a prevalence of $12.5 \%$. Other intestinal flukes, e.g. Haplorchis spp. and $P$. varium, were commonly found in most examined fish species, while $C$. formosanus was recovered from the Crucian carp and ray-finned fishes. Multiparasitism was common in the examined fish. Five fish species were infected with more than one FZT species.

\section{Diversity of snails and trematode infections}

A total of 3,972 snails, representing 7 species, were collected in both Gia Minh and Gia Thinh communes (Table 7). Bithynia fuchsiana, Melanoides tuberculata, Angulyagra polyzonata and Lymnaea viridis were commonly found. They comprised $91.2 \%$ of the total examined snail specimens. Bithynia fuchsiana was particularly common in rice fields and small canals, while Lymnaea spp. were commonly found in rice fields and on floating aquatic macrophytes in lakes. Melanoides tuberculata, $A$. polyzonata, and $P$. canaliculata were present in all habitats, while $S$. aeruginosa were found in rivers, lakes, and dams.

Among the 7 snail species, only M. tuberculata and $B$. fuchsiana were emitting cercariae, with prevalences of $0.92 \%$ and $0.11 \%$, respectively. All infected snails were found in small canals. There was no significant difference

Table 4 Prevalence of FZT in various fish species

\begin{tabular}{|c|c|c|c|c|c|c|c|c|c|}
\hline \multirow[t]{2}{*}{ Fish species } & \multicolumn{3}{|c|}{ Culture fish } & \multicolumn{3}{|c|}{ Wild-caught fish } & \multicolumn{3}{|l|}{ Total } \\
\hline & $\begin{array}{l}\text { No. of } \\
\text { samples }\end{array}$ & $\begin{array}{l}\text { No. of } \\
\text { positive }\end{array}$ & Prevalence (\%) & $\begin{array}{l}\text { No. of } \\
\text { samples }\end{array}$ & $\begin{array}{l}\text { No. of } \\
\text { positive }\end{array}$ & Prevalence (\%) & $\begin{array}{l}\text { No. of } \\
\text { samples }\end{array}$ & $\begin{array}{l}\text { No. of } \\
\text { positive }\end{array}$ & Prevalence (\%) \\
\hline $\begin{array}{l}\text { Silver carp (Hypophtalmychthys } \\
\text { molitrix) }\end{array}$ & 32 & 14 & 43.8 & & & & 32 & 14 & 43.8 \\
\hline Common carp (Cyprinus carpio) & 42 & 8 & 19.0 & 14 & 7 & 50.0 & 56 & 15 & 26.8 \\
\hline Rohu (Labeo rohita) & 35 & 4 & 11.4 & & & & 35 & 4 & 11.4 \\
\hline Tilapia (Oreochromis niloticus) & 63 & 19 & 52.8 & 28 & 4 & 14.3 & 91 & 23 & 25.3 \\
\hline Sharpbelly (Hemiculter leucisculus) & & & & 8 & 4 & 50.0 & 8 & 4 & 50.0 \\
\hline Snakehead murrel (Channa striata) & & & & 7 & 6 & 85.7 & 7 & 6 & 85.7 \\
\hline Crucian carp (Carassius auratus) & & & & 186 & 148 & 79.6 & 186 & 148 & 79.6 \\
\hline Ray-finned fishes (Rasborinus hautus) & & & & 37 & 18 & 48.6 & 37 & 18 & 48.6 \\
\hline Climbing perch (Anabas testudineus) & & & & 31 & 30 & 96.8 & 31 & 30 & 96.8 \\
\hline Total & 172 & 45 & 26.2 & 311 & 217 & 69.8 & 483 & 271 & 56.1 \\
\hline
\end{tabular}


Table 5 Prevalence and intensity of FZT in fish stratified by fish groups and communes

\begin{tabular}{llllll}
\hline Commune & Fish group & No. examined & No. positive & Prevalence (\%) & Mean intensity (range) \\
\hline Gia Minh & Wild-caught & 178 & 106 & 59.6 & $33.823(0.004-499.95)$ \\
& Culture & 156 & 42 & 26.9 & $0.699(0.004-57.804)$ \\
Gia Thinh & Wild-caught & 133 & 84 & 63.1 & $63.741(0.009-826.364)$ \\
& Culture & 16 & 3 & 1.8 & $0.007(0.009-0.01)$ \\
Total & & 483 & 271 & 56.1 & $33.245(0.004-826.364)$ \\
\hline
\end{tabular}

in prevalence of trematodes in snails between the two communes $(\mathrm{p}=0.074)$. Four cercarial types were recorded. Bithynia fuchsiana only released Echinostome cercariae, while $M$. tuberculata released all 4 cercariae types (Table 8 ).

\section{Discussion}

Small trematode eggs, all $<50 \mu \mathrm{m}$ long, were presumed to be either those of $C$. sinensis or of intestinal trematodes of the family Heterophyidae or Echinostomatidae in Vietnam. However, differentiation was not considered reliable by light microscopy. Freshwater fish are the major source of infections with intestinal and liver trematodes [45]. Other flukes are transmitted through plants, snails, crustaceans, amphibians, reptiles and insects [45]. So, all small trematode eggs found in infected humans in study sites, are presumably FZT.

Prevalence of fluke infections in animals in Gia Minh and Gia Thinh communes did not differ, while the chance of people in Gia Thinh becoming infected was 4.62 times higher than for individuals in Gia Minh. Conversely, the prevalence of nematode infections in people in Gia Minh was higher than in Gia Thinh. This difference could be explained by the higher frequency of eating raw fish and other raw foods by the local people. Unfortunately, during this study we did not conduct a survey on the eating habits of the local people.
Infection rates of small trematodes were higher for persons $>18$ years of age and no difference was observed between the working-age group and the over working-age group, a pattern believed to be caused by longer exposure and accumulation of flukes because some trematode species have a long life span $[1,46]$. Mas-Coma \& Bargues [8] mentioned that the longevity of the parasite depends on the host-parasite compatibility and the tolerance of the host. In case of small liver flukes, e.g. C. sinensis, adult stage can survive 15-25 years in humans, but an extreme longevity of over 26-40 years has also been deduced [8]. However, the longevity of small intestinal flukes in humans is not well documented, therefore accumulation of flukes as an explanation for age-related infection patterns is speculative [23]. The infection rates of men with trematodes was higher than of women, and is likely associated with male-oriented social gatherings, during which they consume raw fish or fish products $[23,47]$. The prevalence of nematode infections in the under working-age group were higher than in the two other age groups. Additionally, women had a higher incidence of nematode infections than men. This could be a result of the women and children coming into contact with contaminated soil, either through playing or working, more often than men, leading to greater chance of soil transmitted helminth larvae.

Small trematode infections were common in cats, dogs with lower levels in pigs, in both Gia Minh and Gia

Table 6 Occurrence of FZT metacercariae in different fish species

\begin{tabular}{|c|c|c|c|c|c|c|}
\hline \multirow[t]{2}{*}{ Fish species } & \multirow{2}{*}{$\begin{array}{l}\text { prevalence } \\
\text { (no. positive/ } \\
\text { no. sample) }\end{array}$} & \multicolumn{5}{|l|}{ FZT species found } \\
\hline & & Clonorchis sinensis & Haplorchis spp. & $\begin{array}{l}\text { Procerovum } \\
\text { varium }\end{array}$ & $\begin{array}{l}\text { Centrocestus } \\
\text { formosanus }\end{array}$ & Unidentified \\
\hline Silver carp (Hypophtalmychthys molitrix) & $48.8(14 / 32)$ & 0 & 12 & 0 & 0 & 4 \\
\hline Common carp (Cyprinus carpio) & $26.8(15 / 56)$ & 0 & 13 & 0 & 0 & 0 \\
\hline Rohu (Labeo rohita) & $11.4(4 / 35)$ & 0 & 4 & 1 & 0 & 0 \\
\hline Tilapia (Oreochromis niloticus) & $25.3(23 / 91)$ & 0 & 21 & 2 & 0 & 6 \\
\hline Sharpbelly (Hemiculter leucisculus) & $50.0(4 / 8)$ & 1 & 3 & 0 & 0 & 0 \\
\hline Snakehead murrel (Channa striata) & $85.7(6 / 7)$ & 0 & 6 & 1 & 0 & 0 \\
\hline Crucian carp (Carassius auratus) & $79.6(148 / 186)$ & 0 & 133 & 12 & 3 & 49 \\
\hline Ray-finned fishes (Rasborinus hautus) & $48.6(18 / 37)$ & 0 & 15 & 3 & 1 & 4 \\
\hline Climbing perch (Anabas testudineus) & $96.8(30 / 31)$ & 0 & 27 & 26 & 0 & 0 \\
\hline Total & $56.1(271 / 483)$ & 1 & 234 & 45 & 4 & 63 \\
\hline
\end{tabular}


Table 7 Prevalence of infected snails in the study sites

\begin{tabular}{llllll}
\hline Snail species & Gia Minh commune & & & Gia Thinh commune \\
\cline { 2 - 3 } \cline { 5 - 6 } & No. snails collected & No. snails infected & & No. snails collected & No. snails infected \\
\hline Melanoides tuberculata & 432 & 6 & 1 & 1100 & 1 \\
Bithynia fuchsiana & 794 & 0 & 0 & 179 & 0 \\
Angulyagra polyzonata & 207 & 0 & 103 & 0 \\
Sinotaia aeruginosa & 89 & 0 & 261 & 0 \\
Lymnaea viridis & 324 & 0 & 77 & 0 \\
L. swinhoei & 51 & 7 & 17 & 0 \\
Pomacea canaliculata & 12 & 1909 & & 2063 & 2 \\
Total & & &
\end{tabular}

Thinh communes. Cats and dogs are intentionally fed raw fish by farmers, and are capable of scavenging for raw fish from local ponds and surrounding canals. Pigs, however, become infected only if their owners feed them raw fish or fish waste [48].

At both study sites, local people use domestic animal manure (in some cases, human manure) as fertilizer for the rice fields. This is a significant risk factor for FZT infection, because the eggs in the manure are viable in the wet environment of the rice fields, where snails and fishes are available as the first and the second intermediate hosts. In addition, flooding of the Hoang Long River during the rainy season inundates the rice fields, allowing the trematode eggs present in the animal/human manure to enter the local water system, likely increasing the prevalence and intensity of infected snails.

The diversity and prevalence of FZT infections were found to be high in fishes, although metacercariae of Clonorchis sinensis was only found in the sharpbelly (Hemiculter leucisculus). Local people in the two study sites normally use several freshwater fish species: i.e. silver carp (Hypophthalmichthys molitrix), grass carp (Ctenopharyngodon idellus), rohu (Labeo rohita), and mrigal (Cirrhinus mrigala) to prepare raw fish dishes. Fish are filleted, sliced, and soaked twice in saline solution (1-3\%) before being mixed with rice powder and consumed with herbs and sauce $[49,50]$. Tran et al. [50] found that $11.8 \%$ dishes in restaurants from Nam Dinh province (nearby Ninh Binh province where our study was conducted) were infected with FZT, and freshwater fish were more often

Table 8 Cercariae groups found infecting the first intermediate host

\begin{tabular}{lll}
\hline Cercariae & \multicolumn{2}{l}{ Snail species } \\
\cline { 2 - 3 } & M. tuberculata & B. fuchsiana \\
\hline Xiphidiocercariae & 2 & 0 \\
Echinostome cercariae & 1 & 2 \\
Parapleurolophocercariae & 2 & 0 \\
Furcocercariae & 2 & 0 \\
\hline
\end{tabular}

infected (39.4\%) than brackish water fish (16.0\%). The odds of FZT infection was 2.3 times higher for humans eating raw fish than for those who did not eat raw fish [49]. Metacercariae still remain viable in the prepared fish, even with harsh conditions, i.e. Wykoff [51] found that metacercariae die after 7 hours of desiccation at room temperature, 3 minutes at $65^{\circ} \mathrm{C}$ or 2.5 hours at $39-40^{\circ} \mathrm{C}$ when removed from its host fish. Metacercariae within fish meat under refrigeration remain viable after 40 days, and apparently $50 \%$ were still viable after 50 days when kept at $3-6^{\circ} \mathrm{C}$. Fan [52] studied the effect of freezing or salting of fish on viability of metacercariae of $C$. sinensis. $\mathrm{He}$ found that metacercariae from freshwater fish stored at $-12^{\circ} \mathrm{C}$ for $10-18$ days or $-20^{\circ} \mathrm{C}$ for $3-7$ days or $5-7$ days at heavy salt concentration (3 g salt/10 g fish) remained viable and infective. However, it appears that refrigeration or keeping fish in salt for longer periods ( 2 months) may be suitable for prevention of infection. Local people within the study understood the risk of becoming infected with liver flukes when eating raw fish from information provided by the government through mass media under "national helminthiasis control activities" program [40]. However, they still maintain the habit of consuming raw fish.

The prevalence and intensity of FZT infections in the culture fish group were lower than in the wild-caught fish group. It could be explained by the different density of snails in various environments. Snail density is considerably lower in cage culture than in small canals, lakes, dams, and rivers. In the cage cultures, fishes consume snails, even if they do not feed on snails, they could cause damage or disturbance when probing various items (including snails) for suitability as food [36]. The presence of the black carp, a snail predator [6,53-55], in cages seems to reduce snail density, although the actual presence of the black carp in these cages was not confirmed, just based on interviewing farmers.

Cercariae of the Opisthorchiidae belong to the pleurolophocercarial type. These cercarial type were not found in our survey while Kino et al. [24] found 13.3\% of Melanoides 
tuberculata infected with Clonorchis sinensis in the similar study sites. Nguyen [26] also found that the prevalences of infection with C. sinensis in Parafossarulus striatulus and M. tuberculata were $5.1 \%$ and $10.2 \%$, respectively. The identification of cercariae of $C$. sinensis, however, based on morphological characteristics alone may not be accurate, i.e. species of three trematode families, the Heterophyidae, Opistorchiidae and Cryptogonimiidae, possess pleurolophocercous cercaral type [42]. For this reason, the results of the two references above have been questioned by others [36]. Hence there is need to include molecular tools for identification of both snails and their trematode infections [56].

\section{Conclusions}

In general, Gia Minh and Gia Thinh communes are still endemic areas of FZT and other helminth diseases, although local people are aware of the risks of eating raw fish. Any strategy for controlling helminth diseases must make local people realize the harmfulness of parasites, especially FZT, and they should break the habit of eating raw fish.

\section{Competing interests}

The authors have declare that they have no competing interests.

\section{Authors' contributions}

Conceived and designed the study: NMH, DTD, NTLA, PTV, LXC. Collected data: NMH, DTD, NTLA, BNT, HVH, NVH. Analyzed the data: NMH, HVH, NVH. Wrote the paper: NMH, DTD, NTLA, BNT, PTV, LXC. All authors read and approved the final manuscript.

\begin{abstract}
Acknowledgments
We would like to thank the staff of Preventive Medicine Department in Ninh Binh province and in Gia Vien district for their assistance with many aspects of this study. We are grateful to the farmers in Gia Minh and Gia Thinh communes for their participation in the study. This research is funded by Vietnam National Foundation for Science and Technology (NAFOSTED) under grant number 106-NN.05-2014.21 and the IDRC Ecohealth project "Innovative strategies for Sustainable Control of Asian Schistosomiasis and Other Helminth Zoonoses through Socio-Ecosystem-Based Interventions".
\end{abstract}

\begin{abstract}
Author details
${ }^{1}$ Institute of Ecology and Biological Resources (IEBR), Vietnam Academy of Science and Technology, 18 Hoang Quoc Viet St., Cau Giay district, Hanoi, Vietnam. ${ }^{2}$ Department of Parasitology, National Institute of Malariology, Parasitology and Entomology (NIMPE), 245 Luong The Vinh St., Thanh Xuan district, Hanoi, Vietnam. ${ }^{3}$ Department of Parasitology, National Institute of Veterinary Research (NIVR), 86 Truong Trinh St., Dong Da district, Hanoi, Vietnam. ${ }^{4}$ Research Institute of Aquaculture No. 1 (RIA1), Dinh Bang, Tu Son, Bac Ninh, Vietnam.
\end{abstract}

Received: 27 October 2014 Accepted: 5 January 2015

Published online: 13 January 2015

\section{References}

1. Chai JY, Murrell KD, Lymbery AJ. Fish-borne parasitic zoonoses: status and issues. Int J Parasitol. 2005:35:1233-54.

2. Keiser J, Utzinger J. Emerging foodborne trematodiasis. Emerg Inf Dis. 2005:11:1507-14

3. Murrell KD, Fried B. Food-borne parasitic zoonoses: Fish and plant-borne parasites. In: World class parasites, vol. 11. 233 Spring Street, NewYork: Springer Science and Bisiness Media; 2007.
4. Keiser J, Utzinger J. Food-borne trematodiases. Clin Microbiol Rev. 2009:22:466-83.

5. Lemly AD, Esch GW. Differential survival of metacercariae of Uvulifer ambloptilis (Hughes, 1927) in juvenile centrarchids. J Parasitol. 1983;69:746-9.

6. Nguyen MH, Madsen H, Fried B. Global status of fish-borne zoonotic trematodiasis in humans. Acta Parasitol. 2013;58:231-58.

7. Chai JY, Shin EH, Lee SH, Rim HJ. Foodborne intestinal flukes in Southeast Asia. Korean J Parasitol. 2009;47:69-102.

8. Mas-Coma S, Bargues MD. Human liver flukes: a review. Res Rev Parasitol. 1997:57(Suppl 3-4):145-218.

9. Bundy DA, Chandiwana SK, Homeida MM, Yoon S, Mott KE. The epidemiological implications of a multipleinfection approach to the control of human helminth infections. Trans R Soc Trop Med and Hyg. 1991;85:274-6.

10. Chai JY, Hong ST, Lee SH, Lee GC, Min YI. A case of echinostomiasis with ulcerative lesions in the duodenum. Korean J Parasitol. 1994;32:201-4.

11. Chattopadyay UK, Das MS, Pal D, Das S, Mukherjee A. A case of echinostomiasis in a tribal community in Bengal. Ann Trop Med Parasitol. 1990;84:193

12. Fried B, Graczyk TK, Tamang L. Food-borne intestinal trematodiases in humans. Parasitol Res. 2004;93:159-70.

13. MacLean JD, Cross JH, Mahanty S. Liver, lung and intestinal fluke infections. In: Guerran RL, Walker DH, Weller PF, editors. Tropical Infectious Diseases, vol. 2. Philadelphia: Churchill Livingston; 2006. p. 1039-57.

14. Ditrich O, Giboda M, Scholz T, Beer SA. Comparative morphology of eggs of the Haplorchiinae (Trematoda: Heterophyidae) and some other medically important heterophyid and opisthorchiid flukes. Folia Parasitol. 1992;39:123-32.

15. Watthanakulpanich D, Waikagul J, Maipanich W, Nuamtanong S, Sanguankiat S, Pubampen S, et al. Haplorchis taichui as a possible etiologic agent of irritable bowel syndrome-like symptoms. Korean J Parasitol. 2010;48:225-9.

16. Fang YY, Chen YD, Li XM, Wu J, Zhang QM, Ruan CW. Current prevalence of Clonorchis sinensis infection in endemic areas of China. Chin J Parasitol Parasitic Dis. 2008;26:81-6.

17. Lun ZR, Gasser RB, Lai DH, Li AX, Zhu XQ, Yu XB, et al. Clonorchiasis: a key foodborne zoonosis in China. Lancet Infect Dis. 2005;5:31-41.

18. Yossepowitch O, Gotesman T, Assous M, Marva E, Zimlichman R, Dan M. Opisthorchiasis from imported raw fish. Emerg Inf Dis. 2004;10:2122-6.

19. Rim HJ, Farag HF, Sornmani S, Cross JH. Food-borne Trematodes: Ignored or Emerging? Parasitol Today. 1994;10:207-9.

20. Chai JY. Echinostomes in humans. In: Fried B, Toledo R, editors. The biology of echinostomes. From the molecule to the community. Springer: New York, NY; 2009. p. 147-83.

21. Lima-dos-Santos CAM, Howgate P. Fishborne zoonotic parasites and aquaculture: A review. Aquaculture. 2011:318:253-61.

22. World Health Organization [WHO]. The World Health Report: Changing History. Geneva: WHO Library Cataloguing in Publication Data; 2004. p. 1-170.

23. Do TD, Nguyen VD, Waikagul J, Dalsgaard A, Chai JY, Sohn WM, et al. Fishborne Zoonotic Intestinal Trematodes, Vietnam. Emerg Infect Dis. 2007;13:1828-33.

24. Kino H, Inaba H, Nguyen VD, Le VC, Dang TS, Hoan TH, et al. Epidemiology of clonorchiasis in Ninh Binh province, Vietnam. Southeast Asian J Trop Med Public Health. 1998;29:250-4.

25. Nguyen $T H$, Nguyen VD, Murrell KD, Dalsgaard A. Occurrence and species distribution of fishborne zoonotic trematodes in wastewater-fed aquaculture in northern Vietnam. Trop Med Int Health. 2007;12:66-72.

26. Nguyen VD, Murrell KD, Cong LD, Cam PD, Chau LV, Toan ND, et al. The food-borne trematode zoonoses of Vietnam. Southeast Asian J Trop Med Public Health. 2003;34:12-34.

27. World Health Organization [WHO]. Manual of Basic Techniques for a Health Laboratory - $2^{\text {nd }}$ edit. Geneva: WHO Library Cataloguing in Publication Data; 2003. p. 1-398.

28. Elkins DB, Mairiang E, Sithithaworn P, Mairiang P, Chaiyakum J, Chamadol N, et al. Cross-sectional patterns of hepatobiliary abnormalities and possible precursor conditions of cholangiocarcinoma associated with Opisthorchis viverrini infection in humans. Am J Trop Med Hyg. 1996;55:295-301.

29. Nguyen TLA, Phuong TN, Ha HG, Luong TT, Johansen MV, Murrell KD, et al, Evaluation of techniques for detection of small trematode eggs in feces of domestic animals. Vet Parasitol. 2008;156:346-9.

30. Willingham AL, Johansen MV, Barnes BH. A new technic for counting Schistosoma japonicum eggs in pig feces. Southeast Asian J Trop Med Public Health. 1998;29:128-30. 
31. Phan TV, Ersbøll AK, Bui TQ, Nguyen HT, Murrell D, Dalsgaard A. Fish-borne zoonotic trematodes in cultured and wild-caught freshwater fish from Red River delta, Vietnam. Vetor Borne Zoonotic Dis. 2010;10 Suppl 9:861-6.

32. World Health Organization [WHO]. Control of foodborne trematode infections. In: Report of a WHO Study Group. WHO study group on the control of foodborne trematode infections. Geneva: WHO Library Cataloguing in Publication Data; 1995. p. 1-157.

33. Tran TKC, Dalsgaard A, Turnbull JF, Tuan PA, Murrell KD. Prevalence of zoonotic trematodes in fish from a Vietnamese fish-farming community. J Parasitol. 2008:94:423-8.

34. Pearson JC, Ow-Yang CK. New species of Haplorchis from Southeast Asia, together with keys to the Haplorchis-group of heterophyid trematodes of the region. Southeast Asian J Trop Med Public Health. 1982;13:35-60.

35. Scholtz T, Ditrich O, Giboda M. Differential diagnosis of opisthorchid and heterophyid metacercariae (Trematoda) infecting flesh of cyprinid fish from Nam Ngum Dam Lake in Lao PDR. Southeast Asian J Trop Med Public Health. 1991;22:171-3.

36. Kaewkes S. Taxonomy and biology of liver flukes. Acta Trop. 2003:88:177-86.

37. Bui TD, Madsen H, Dang TT. Distribution of freshwater snails in family-based VAC ponds and associated water bodies with special reference to intermediate hosts of fish-borne zoonotic trematodes in Nam Dinh province, Vietnam. Acta Trop. 2010;116:15-23.

38. Madsen $H$, Coulibaly G, Furu P. Distribution of freshwater snails in the river Niger basin in Mali with special reference to the intermediate host of Schistosomes. Hydrobiology. 1987;146:77-88.

39. Brandt RAM. The non-marine aquatic mollusca of Thailand. Arch Molluskenkd. 1974;105:1-423.

40. Dang NT. Identification of freshwater invertebrates in Northern Vietnam. Vietnamese: Science and Technical Press; 1980. p. 440-90 (in Vietnamese).

41. Ginetsinskaya TA. Trematodes, their life cycles, biology and evolution. NewDelhi: Amerind Publishing Company, Pvt; 1988 (Translation of the original Russian edition, 1968).

42. Schell SC. Handbook of Trematodes of North America (North of Mexico). Idaho: University Press of Idaho; 1985.

43. Hilbe JM. Logistic Regression Models. Florida: Chapman \& Hall/CRC, Taylor \& Francis Group; 2009

44. Hilbe JM. Negative Binomial Regres. Cambridge: Cambridge University Press; 2008.

45. Yu SH, Mott KE. Epidemiology and morbidity of Food-borne intestinal trematode infections. In: Report of World Health Organization [WHO]. Schistosomiasis Control Unit, Division of Control of Tropical Diseases. Geneva: WHO Library Cataloguing in Publication Data; 1994. p. 1-26.

46. Sithithaworn P, Haswell-Elkins M. Epidemiology of Opisthorchis viverrini. Acta Trop. 2003;88:187-94.

47. Grundy-Warr C, Andrews RH, Sithithaworn P, Petney TN, Sripa B, Laithavewat $L$, et al. Raw attitudes, wetland cultures, life-cycles: Socio-cultural dynamics relating to Opisthorchis viverrini in the Mekong Basin. Parasitol Int. 2012;61:65-70

48. Nguyen TLA, Phuong TN, Johansen MV, Murrell KD, Phan TV, Dalsgaard A, et al. Prevalence and risks for fishborne zoonotic trematode infections in domestic animals in a highly endemic area of North Vietnam. Acta Trop. 2009;112:198-203.

49. Phan TV, Ersbøll AK, Do TD, Dalsgaard A. Raw-fisheating behavior and fishborne zoonotic trematode infection in people of Northen Vietnam. Foodborne Pathog Dis. 2011:8:255-60.

50. Tran TKC, Murrell KD, Madsen H, Nguyen VK, Dalsgaad A. Fishborne zoonotic trematodes in raw fish dishes served in restaurants in Nam Dinh province and Hanoi, Vietnam. J Food Protect. 2009;72:2394-9.

51. Wykoff DE. Studies on Clonorchis sinensis III. The host-parasite relations in the rabbit and observations on the relative susceptibility of certain laboratory hosts. J Parasitol. 1958;44:461-6.

52. Fan PC. Viability of metacercariae of Clonorchis sinensis in frozen or salted freshwater fish. Int J Parasitol. 1998;28:603-5.

53. Ben-Ami F, Heller J. Biological control of aquatic pest snails by the black carp Mylopharyngodon piceus. Biol Control. 2001;22:131-8.

54. Nico LG, Williams JD, Jelks HL. Black carp biological synopsis and risk assessment of an introduced fish. Bethesda, Maryland: American Fisheries Society Special Publication 32; 2005. p. 1-337.
55. Nguyen MH, Nguyen VD, Stauffer JT, Madsen H. Use of black carp (Mylopharyngodon piceus) in biological control of intermediate host snails of fish-borne zoonotic trematodes in nursery ponds in the Red River Delta, Vietnam. Parasit Vectors. 2013;6:142

56. Born-Torrijos A, Poulin R, Raga JA, Holzer AS. Estimating trematode prevalence in snail hosts using a single-step duplex PCR: how badly does cercarial shedding underestimate infection rates? Parasit Vectors. 2014;7:243.

\section{Submit your next manuscript to BioMed Central and take full advantage of:}

- Convenient online submission

- Thorough peer review

- No space constraints or color figure charges

- Immediate publication on acceptance

- Inclusion in PubMed, CAS, Scopus and Google Scholar

- Research which is freely available for redistribution 